\title{
НЕКОТОРЫЕ НАУЧНЫЕ ВОЗЗРЕНИЯ К ЦИВИЛИЗАЦИОННОЙ ТИПОЛОГИИ ГОСУДАРСТВ
}

\author{
(c) 2021 Бышов Денис Викторович \\ кандидат исторических наук \\ доцент кафедры правовых дисциплин Юридического факультета \\ Мордовский государственный университет имени Н.П. Огарева, Россия, Саранск \\ E-mail: bishovdv@mail.ru
}

В рамках данной статьи рассматриваются научные воззрения относительно цивилизационного подхода к типологии государств: А. Тойнби, П. Мотта, Г. Кельзена, Р. Дарендорфа и др. Приводятся также и другие концепции к типологии государств, исходя из иных черт социального характера и классовой структуры.

Ключевые слова: типология государств, цивилизация, социальная организация, классовая структура, демократия, автократия, идеальный тип.

В изучении развития государств цивилизационный подход все больше оценивается современными исследователями. Исследования ученых в настоящее время указывают на одномерность (однолинейность) в применении формационного подхода в оценивании типов государств. История человечества показывает многоукладность в своем развитии, что важно в понимании глубиной сущности общества и его организованности. И формационный подход не в полной мере может объективно оценивать общественные процессы в государствах.

Во-первых, при рассмотрении материального базиса не учитывается такой момент, как многогранность, которая неотделима историю развития общества. Учитывание этого важного момента значительно трансформирует обычные мнения о постулатах динамики материального базиса. Сущность разнообразных экономических укладов в большей мере заключается не только в базисном устройстве, но и в особенностях, распада старых типов экономических систем и возникновения современных хозяйственных форм.

Во-вторых, при формационном рассмотрении структуры классовых обществ их социальный состав значительно сужается, так как в основном учитываются только классыантагонисты, остальные же социальные слои находятся за пределами исследования; они не вписываются, в традиционную модель классового противостояния. Тем самым обедняется социальная картина общественной, в том числе государственно-правовой жизни народов.
При изучении психологических, языковых и культурных особенностей населения, важно делать вывод об оценке окружающей среды, о том, какое значение имеет определенная часть людей, и человек в мировом пространстве. Структура данных аспектов является основополагающими в развитии базисных и духовных особенностей общества, они обусловливают и организовывают единство народонаселения, являются ядром его формирования. Социальные противоречия деградируют и ухудшают эти ценности, однако последние не утрачивают при этом главного своего надклассового, общенационального характера.

Исследователи выделяют в цивилизационном подходе минусы и плюсы. Как подчеркивает М. Марченко: «Понятие «цивилизация» выглядит весьма аморфно и неопределенно. Данное понятие по справедливому замечанию исследователей, принадлежит к числу тех явлений и понятий, которые не поддаются сколько-нибудь строгому и однозначному определению. Если попытаться как-то объединить различные значения ее определения, то, очевидна мы получим скорее «некий интуитивный образ, чем логически выверенную категорию». И все же за этим образом просматривается определенная реальность в виде целостности материальной и духовной жизни людей в определенных пространственных и временных границах» [1, С. 196].

Цивилизация, по мнению американского политолога С.Хантингона, представляет собой «некую культурную сущность». Деревни, регионы, этнические группы, народы, религиозные 
общины, замечает автор, обладают особой культурой, отражающей различные уровни культурной неоднородности. Исходя из этого цивилизацию можно определить как культурную общность наивысшего ранга, как самый широкий уровень культурной идентичности людей [1, С. 197].

Вообще цивилизация определяется, из таких моментов как духовный уровень, традиции, язык, культура, нормы морали.

Подобную конфигурация в отношении цивилизации усматривал европейский историк А.Тойнби. С его точки зрения цивилизация это социальное сообщество людей, например, в культуре, традиции, религии, живописи.

Вообще если говорить конкретно про А. Тойнби, то он раскрыл и подробно изучил понятие цивилизации, под этим понятием ученый определял относительно органичное состояние общества, которое включает в себя психологические, духовные, культурные, экономические, психологические факторы. В цивилизациях он подчёркивал локальность и замкнутость. Тойнби вел речь о локальных цивилизациях, которые он считает замкнутыми в себе, изолированными друг от друга, абсолютно неповторимыми, уникальными. Каждая цивилизация проходит один и тот же цикл, состоящий из пяти этапов: рождения, роста, перелома, размножения и гибели. Погибнув, цивилизации исчезают - не оказывая существенного влияния на ход всемирной истории. В работах Тойнби указывается различные категорий цивилизаций. В своих трудах он полагает, что существуют ряд цивилизаций: дальневосточная, японо-корейская, византийско-ортодоксальная, индийская, китайская, русско-ортодоксальная, западная и арабская. Всего их восемь. Данные цивилизации склоны к распаду. Хотя западная цивилизация находится в динамическом развитии. Западная цивилизация, по мнению Тойнби, имеет наибольшие шансы избежать разложения и гибели. Этот шанс заключается в христианской религии, являющуюся спасительным бальзамом, который сможет сохранить западную цивилизацию нетленной, вопреки разрушительным тенденциям и явлениям дезинтеграции, раскола, классовой борьбы [2, С. 86].

Теория Тойнби отрицает поступательный характер общественного развития. Развитие, утверждает он, может идти только циклически, по кругу
В своих работах П. Мотт определяет несколько периодов формирования общества, опираясь на понятие «социальная организация». Данные аспект указывает на многие организации, созданные людьми. П. Мотт выделяет такие организации, как семью, общество пчеловодов, клубы по интересам, общество рыболовов, компанию «Макдональдс», учеников школы и т.п. С точки зрения автора, принцип взаимодействия людей, является основой социальной организации людей общества. Он выделяет ряд типов социальных организаций людей:

1. социальную организацию догородского общества;

2. социальную организацию аграрного общества;

3. социальную организацию общества, вступившего на путь индустриализации;

4. социальную организацию, массового индустриального общества [3, С. 92].

Основным моментом определения стадий развития общества у П. Мотта является простое обоснование форм общественной организации. Эталоном, по сути, берется капиталистический образ общества, и с этих аспектов рассматриваются прошлые этапы развития человечества [3, С. 93].

В числе ведущих позиций научной мысли Европы представляется теория двух определений государств: демократии и автократии, которая относит типы государств к классификации форм государственного устройства. Г Кельзен считает, что в понимании типологии государств надо указывать на свободу в обществе. Автор указывает: «Если атрибутом систематизации брать порядок, где, опираясь на конституцию, образуется законность, то, это можно больше отнести для систематизации, то взамен трех мы получим две формы конституции: демократию и автократию. Эта разница опирается на принципы политического плюрализма» [4, С. 554]. Опираясь на его работы, сейчас существует чаще всего две разновидности государства в зависимости от того, какое положение занимает воля человека в понимании правового устройства. Если член общества помогает созданию правовой системы и порядка, то здесь можно говорить о демократии, если наоборот, то автократия. По с точки зрения ученого, демократия и автократия - совершенные формы, которые подчеркивают многообразие политических форм.

Ученый из США Р.Макайвер разделяет госу- 
дарства на две категории с точки зрения того, могут ли государственные интересы совпадать с интересами большинства. С этой точки зрения Р. Макайвер разделяет государства династические, где интересы государства не совпадают с большинством мнений, и демократические государства, где общая воля идентична государства, где народ поддерживает правительство. В первой структуре ученый указывает «классовые» державы, императорские государства, а также государства, которые называются демократическими (те. псевдодемократические), где власть формируется элитной составной социума. Ко второй категории ученый указывает на те государства, где взаимодействие между государством и индивидом основываются на равенстве и справедливости, где власть дает гражданину свободное волеизъявление своих прав [5, С. 93].

В этом отношении особое значение Дарендорф придает «социальной мобильности», которая и должна привести к стиранию классовых различий. С одной стороны, Дарендорф настаивает на вечности классового деления, поскольку вечной, с его точки зрения, является категория государства. «Господство,- может быть централизованным или децентрализованным, абсолютным или ограниченным, но во всяком случае оно есть функциональный императив социальных организаций» [6, С. 251]. Однако, с другой стороны, Дарендорф готов признать, что «индустриальное» (западное), по его терминологии, общество постепенно превращается в бесклассовое. Мыслимо такое общество, говорит он, в котором хотя и имеются позиции господства и подчинения, но нет постоянных закрепощенных носителей этих позиций. «Группы интереса», благодаря мобильности, превращаются в неоформленные, текучие образования, и это ведет к смягчению, а затем к полной ликвидации классового конфликта. Принадлежность к классам становится тогда чисто случайным, те принципиально нестабильным явлением. «Постоянная текучесть классов делает защиту их интересов практически невозможной. Вследствие этого бесклассовое общество с мобильностью внутри поколений является категорией, имеющей реальное значение»,- утверждает социолог.

Сходные с Дарендорфом взгляды проповедует известный американский социолог С.Липсет. Правда, Липсет полемизирует с Дарендорфом, упрекая его в том, что он слишком подчеркивает моменты раскола, конфликта внутри «индустри- ального общества» и недостаточное внимание уделяет проблеме стабильности общества. По словам Липсета, «когда конфликт заинтересованных групп закончен, «конфликтующие» стороны организации способствуют интеграции и прочности общества. Профсоюзы не должны рассматриваться только в их функции экономического раскола. Они служат также тому, чтобы объединять своих членов в более крупный политический орган и закладывают основу для формирования их лояльности к системе в целом» [2, C. 70].

Основополагающей политикой в Европе, рассуждает Липсет, является положение о «коллективной сделки». а классовые противоречия практически не ощутимы. «Классовые противоречия, которые основываются на демократии будут без влияния идеологических аспектов, без красных знамён, без революционных мирных шествий»,- заявляет Липсет, т е. если ситуация такова, то нужно быть готовым к столкновению идей и классовых противоречий. И важно учесть, что борьба будет демократической, цивилизованной и культурной.

Некоторые ученые идут по линии субъективного толкования типологии общества. Речь идет о создании таких форм, которые не имеют подобия в современной жизни, но при их содействии возможно, по их мнению, упорядочить поток исторических событий. В свое время М.Вебер противопоставил марксистскому учению об общественно-экономических формациях понятие «идеального типа», которое, по его мнению, могло систематизировать определенные реалии общества. «Идеальные типы» были произвольными мыслительными конструкциями, где ученые классифицировали бы общественные явления, которые, в силу своей природы, не поддаются научному обобщению. «Идеальный тип» - это «определенный образ в голове», а не ретроспектива, и она не является графиком, куда реальность вставляется в форме отдельного элемента [7, С. 21].

Этот принцип безупречного понятия, с точки зрения идеализма. В реальности оно оценивается для понимания эмпирического содержания ее составных частей.

Таким образом, типология государств по цивилизационному признаку посвящено значительное количество научных изысканий, но тем не менее данный подход определяется всё еще нечеткостью и еще недостаточной дорабо- 
танностью. Хотя, на самом деле теория цивили- так как позволяет рассматривать государство не зационного подхода является абсолютно реаль- только как классовое строение, но и как опреденой, научно обоснованной. Цивилизационный ленную духовно-культурную структуру.

подход более многогранен, чем формационный,

\section{Библиографический список}

1. Марченко М. Н. проблемы общей теории государства и права: в 2 т. Т. 1. Право. М.: ТК Велби, Проспект, 2008. $657 \mathrm{c}$.

2. Попов С.И. Критика современной буржуазной социологии. М.: Мысль, 1970. - 109 с.

3. Рожкова Л. П. Принципы и методы типологии государства и права / Под ред. М.И. Байтина. Саратов: Изд-во Сарат. ун-та, 1984.116 с.

4. История политических и правовых учений / Под ред. О. Э. Лейста. М.: Юрид. лит., 1997. 576 с.

5. Яковенко Е. Д. О цивилизационном подходе к типологии государства // Инновационное развитие: потенциал науки и современного образования: сборник статей IV Международной научно-практической конференции. 2019. Пенза: Из-во: «Наука и Просвещение», 2019. С. 93-94.

6. Дарендорф Р. Современный социальный конфликт. Очерк политики свободы. М.: РОССПЭН, 2002. 284 с.

7. Кораблев Л. В. Концепция «идеальных типов» «социального действия» Макса Вебера и ее теоретическая несостоятельность: автореф. дис. ... канд. философ. наук: М.: Изд-во Моск. ун-та, 1969. 24 с. 